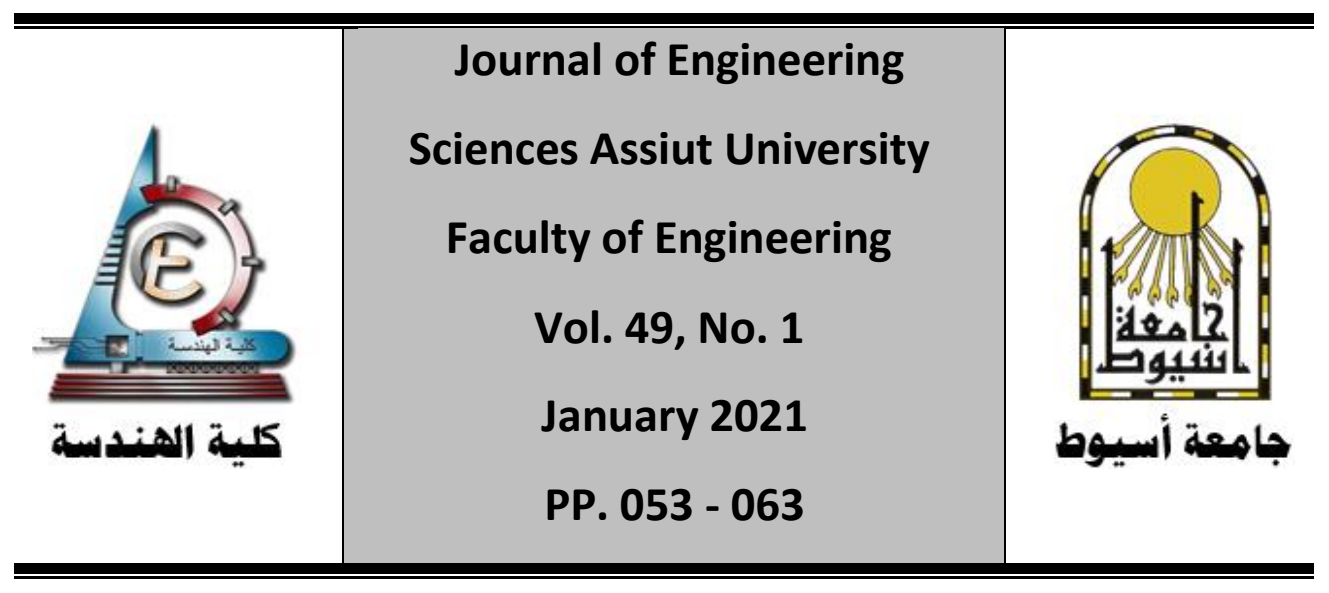

\title{
STUDY OF THE BEHAVIOR OF BINARY MIXTURE GRINDING USING THE FIXED-TIME LOCKED - CYCLE TESTS
}

\author{
Sherein Ahmed M.E. Rizk \\ Faculty of Engineering, Beni-Suef University E-Mail address: \\ sherein.rizk@gmail.com
}

Received: 5 October 2020; Revised: 2 November 2020; Accepted: 2 November 2020

\begin{abstract}
:
Ores are generally very heterogeneous in their physical properties. Variation of the ore from a mine can cause the mill feed to vary in grindability. In the comminution of heterogeneous materials, an understanding of how different constituents behave by themselves and how they interact with each other may prove useful not only for understanding grinding mill action but also for obtaining the optimum values which used in mathematical modelling. Locked cycle tests show that in the grinding of mixtures relatively long time is required to attain steady state, during which the composition of the mill contents continuously change. Therefore, the main objective of this work is to study the behavior of the components of limestone-quartz binary mixture at different ratios of mixing from the start point to attain the steady state condition using the experimental fixed-time locked-cycle tests. It is shown that attaining the steady state condition in a fixed time locked cycle is faster with low circulating load for soft material than those for hard one when they ground separately. As admixture, the hard component appearance increases gradually with decreasing the fineness of the product as its percentage increases in the feed.
\end{abstract}


Sherein Ahmed M.E. Rizk et al., Study of the Behavior of Binary Mixture ...

Keywords: Comminution of binary mixtures; psedu closed circuit; fixed time locked; cycle; grinding circuits

\section{Introduction}

During the past few years, extensive efforts have been directed towards automatic control of grinding circuits to optimize the utilization of comminution energy and the recovery of minerals by minimizing overgrinding [1-3]. Testing the response of an industrial scale grinding system to variations in operating variables can be an expensive undertaking. On the other hand, laboratory-scale experimentation that simulate continuous closed-circuit grinding can provide detailed information which might be extended to predicting the response of fullscale comminution systems under dynamic conditions [4-7]. Locked cycle grinding tests are widely used for assessing the grindability of industrial minerals and ores, for the design and scale up of industrial mills, and for studying the likely behavior of industrial grinding circuits under different operating conditions [8-11].

These tests experimentally simulate on the laboratory scale a tumbling mill operating under plug flow conditions in a closed loop with a classifier which may or may not be perfect. It is well known that locked cycle tests are time consuming, laborious, and prone to experimental errors. Therefore, based on appropriate mathematical algorithms, several accurate simulation schemes have been proposed to economize on the experimental component of these tests [12-16]. In a locked cycle grinding test, a fixed amount of crushed feed solid material is ground in tumbling mill and the comminuted product is screened on a prescribed mesh of grind. The oversize component is combined with new makeup feed and the grinding cycle is repeated. The cycles are continued until in theory at least, the grinding system reaches a steady state-that the weight of the recycle material, the new makeup feed and the undersize product become constant. The locked cycle test at equilibrium is equivalent to the steady state [6]. Considerable advances have been made in the last two decades in evolving kinetic models for the analysis of comminution operations. Through such models in conjunction with mill transport models, mill design, operation and control can now be conceived in a rational and meaningful way [12]. Most of the published work to test these models has been carried out with single minerals or more-or-less homogeneous materials [17-20]. 
A calcite-quartz mixture was employed as a feed for conducting fixedtime locked cycle grinding tests by Kapur et al [13]. They showed that multicomponent feeds comprising hard and soft minerals in different proportions should provide a more realistic model representation on the dynamic of closed-circuit grinding heterogeneous industrial ore. These complex ores, of course, are of primary importance, both in terms of the tonnage ground and the comminution energy expended. On the other hand, compared to single-component feeds, much more experimental effort is required for locked-cycle grinding of mixture feed, not only is the numbers of cycles needed to attain steady state significantly higher, but also it is necessary to analyze the composition of the recycling mass or the finished product at end of each cycle. Therefore, the objective of the work presented in this paper is to study the behavior of the components of the limestone-quartz binary mixture in a locked cycle at different ratios of mixing from the start point to the steady state condition using the experimental fixed-time locked-cycle tests technique.

\section{Experimental Work}

Given amounts of limestone and quartz of size $-4+2 \mathrm{~mm}$ are ground separately and as admixture in a batch ball mill for fixed times. The experimental work was conducted using a ball mill of $14 \mathrm{~cm}$ length and $16 \mathrm{~cm}$ inside diameter with a volume occupied with the total load (grinding media and ore charge) of 55\% of the total mill volume. $90 \%$ of the voids between media charge was filled with ore. The grinding media consisted of 54 balls of $2.5 \mathrm{~cm}$ diameters, 108 balls of $2 \mathrm{~cm}$ diameter and 122 steel balls of $1.5 \mathrm{~cm}$ diameter. The mill was operated with $80 \mathrm{rpm}$ which represent $75 \%$ of its critical speed. The fixed grinding times were 2 minutes for limestone, and 5 minutes for quartz and admixture of limestone and quartz. The percentage of quartz weight was changed to be $20 \%, 40 \%, 60 \%$ and $80 \%$ of the total admixture weight which filled the interstitial voids between balls. This corresponding to $80 \%, 60 \%$, $40 \%$ and $20 \%$ of limestone weight respectively as illustrated in Table. (1). Product of each ground fixed period is sieved on $-200 \mu \mathrm{m}$ screen. The oversize material is returned to the mill with sufficient new feed ($4+2 \mathrm{~mm}$ ) to maintain the holdup constant. The total material charge is ground again for the subsequent fixed period. This step is repeated until steady state is attained. The weight of each component in the admixture experiments was appointed by dilute HCL dissolution. 
Sherein Ahmed M.E. Rizk et al., Study of the Behavior of Binary Mixture ...

Table (1) Weights of separate and admixture of limestone and quartz

\begin{tabular}{|c|c|c|c|c|c|c|c|c|c|}
\hline \multicolumn{2}{|c|}{ separate } & \multicolumn{8}{|c|}{ Mixture of limestone and quartz } \\
\hline \multirow{2}{*}{$\begin{array}{l}\text { Quartz } \\
\text { (gm) }\end{array}$} & \multirow{2}{*}{$\begin{array}{l}\text { Limestone } \\
\text { (gm) }\end{array}$} & \multicolumn{2}{|c|}{$20 \% Q$} & \multicolumn{2}{|c|}{$40 \% Q$} & \multicolumn{2}{|c|}{$60 \%$ Q } & \multicolumn{2}{|c|}{$80 \% Q$} \\
\hline & & Q & $\overline{\mathrm{LL}}$ & $Q$ & $\overline{\mathrm{L}}$ & $Q$ & $\overline{\mathrm{LL}}$ & $Q$ & $\overline{\mathrm{LL}}$ \\
\hline 810 & $\overline{7700}$ & 162 & 560 & 324 & 420 & 486 & 280 & 648 & 140 \\
\hline
\end{tabular}

\section{Results and Discussions:}

Grinding each of limestone and quartz separately illustrated that reaching the steady state for limestone (18 minutes) with a circulating load of $178 \%$ is faster than that of quartz (45 minutes) with a circulating load of $188 \%$. The final product $(-200 \mu \mathrm{m})$ of limestone is finer than that of quartz as shown in Table (2) and Fig. (1) these findings support those obtained by Fuerstenau and Venkataraman [12], and Kapur et al [13]. This behavior may be due to the high difference in their hardness.

Table (2) Particle size analysis of the ground limestone and quartz final products $(-200 \mu \mathrm{m})$ at the steady state condition when they ground separately

\begin{tabular}{|c|c|c|c|c|c|c|c|c|c|}
\hline \multirow{2}{*}{$\begin{array}{l}\text { Particle size } \\
(\mu \mathrm{m})\end{array}$} & \multirow{2}{*}{$\begin{array}{c}\text { Mean } \\
\text { particle } \\
\text { size }(\mu \mathrm{m}) \\
\left(D_{i}\right)\end{array}$} & \multicolumn{4}{|c|}{ Limestone } & \multicolumn{4}{|c|}{ Quartz } \\
\hline & & $\begin{array}{l}\text { Wt.\% } \\
\text { ret. }\end{array}$ & $\begin{array}{c}\text { Wt. \% } \\
\text { ret. } \\
\times D_{i} \\
\end{array}$ & $\begin{array}{c}\text { Comm. } \\
\text { wt\% } \% \\
\text { ret. }\end{array}$ & $\begin{array}{c}\text { Comm. } \\
\text { wt } \% \\
\text { passed }\end{array}$ & $\begin{array}{l}\text { Wt. \% } \\
\text { ret. }\end{array}$ & $\begin{array}{c}\text { Wt. \% } \\
\text { ret. } \\
\times D_{i}\end{array}$ & $\begin{array}{c}\text { Comm. } \\
\text { wt } \% \\
\text { ret. }\end{array}$ & $\begin{array}{c}\text { Comm. } \\
\text { wt\% } \\
\text { passed }\end{array}$ \\
\hline$-200+160$ & 180 & 14.52 & 2613.9 & 14.52 & 100.00 & 47.4 & 853.2 & 47.4 & 100.0 \\
\hline$-160+125$ & 142.5 & 11.29 & 1608.8 & 25.81 & 85.48 & 10.6 & 1510.5 & 58.0 & 52.6 \\
\hline$-125+100$ & 112.5 & 7.10 & 798.8 & 32.91 & 74.19 & 10.2 & 1147.5 & 68.2 & 42 \\
\hline$-100+71$ & 85.5 & 12.26 & 1048.2 & 45.17 & 67.09 & 14.4 & 1231.2 & 82.6 & 31.8 \\
\hline$-71+63$ & 67 & 5.81 & 389.3 & 50.98 & 54.83 & 6.8 & 455.6 & 89.4 & 17.4 \\
\hline$-63+0.0$ & 31.5 & 49.02 & 1544.1 & 100.00 & 49.02 & 10.6 & 333.9 & 100.0 & 10.6 \\
\hline \multicolumn{2}{|c|}{ Median diameter $(\mu \mathrm{m})$} & & 80.03 & & & & 132.11 & & \\
\hline
\end{tabular}




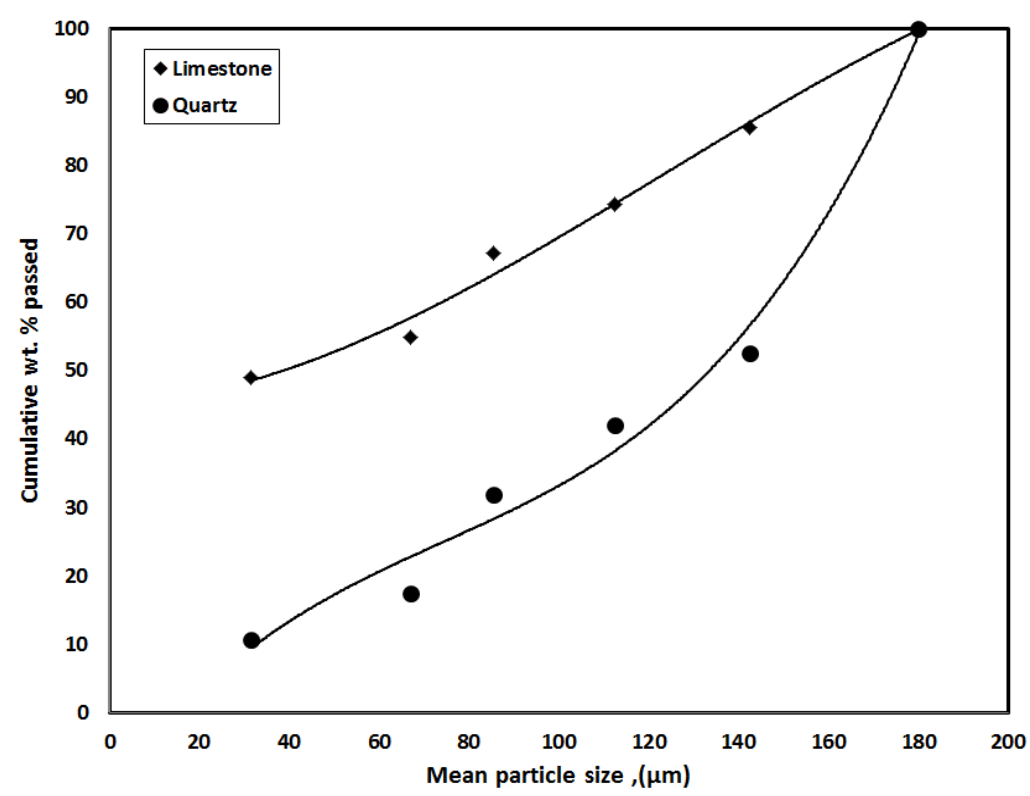

Fig. (1) Particle size distribution of separately ground limestone and quartz final products $(-200 \mu \mathrm{m})$ at the steady state condition

Results of the admixture study from $20 \%$ to $80 \%$ quartz are listed in Table (3). This table contains the particle size analysis of the product at the steady state condition for the different studied admixtures. This table includes also the median diameter of each studied mixture as well as the percentage of quartz in the product of each studied mixture. Fig. (2) represents the effect of the percentage of quartz in the feed on its appearance in the product at the steady- state conditions. From this figure it is clear that, the appearance of quartz increases gradually with a constant slope in the product as its percentage increased in the feed. This behavior may be due to that quartz is mono mineral. This interpretation agrees with that proposed by Powell and Morrison [15]. Fig. (3) clears that the median of the ground mixture increases as the percentage of quartz in the feed increases. This behavior may be attributed to the higher strength of quartz as it transfers the energy from balls to limestone particles which increases their grindability. Fig. (4) Represents the particle size distribution of each studied mixture. This figure reflects also 
Sherein Ahmed M.E. Rizk et al., Study of the Behavior of Binary Mixture ...

that the product becomes coarser as the percentage of quartz increases in the feed.

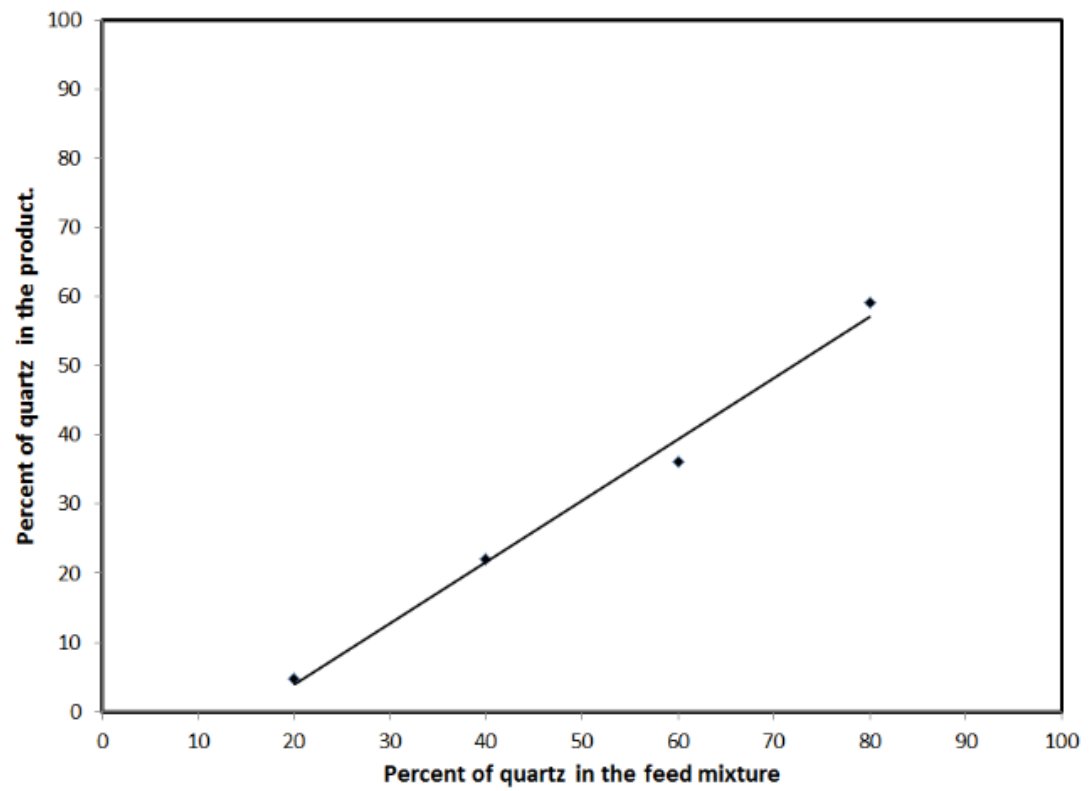

Fig. (2) Effect of the percentage of quartz in the feed mixture on its percentage in the product.

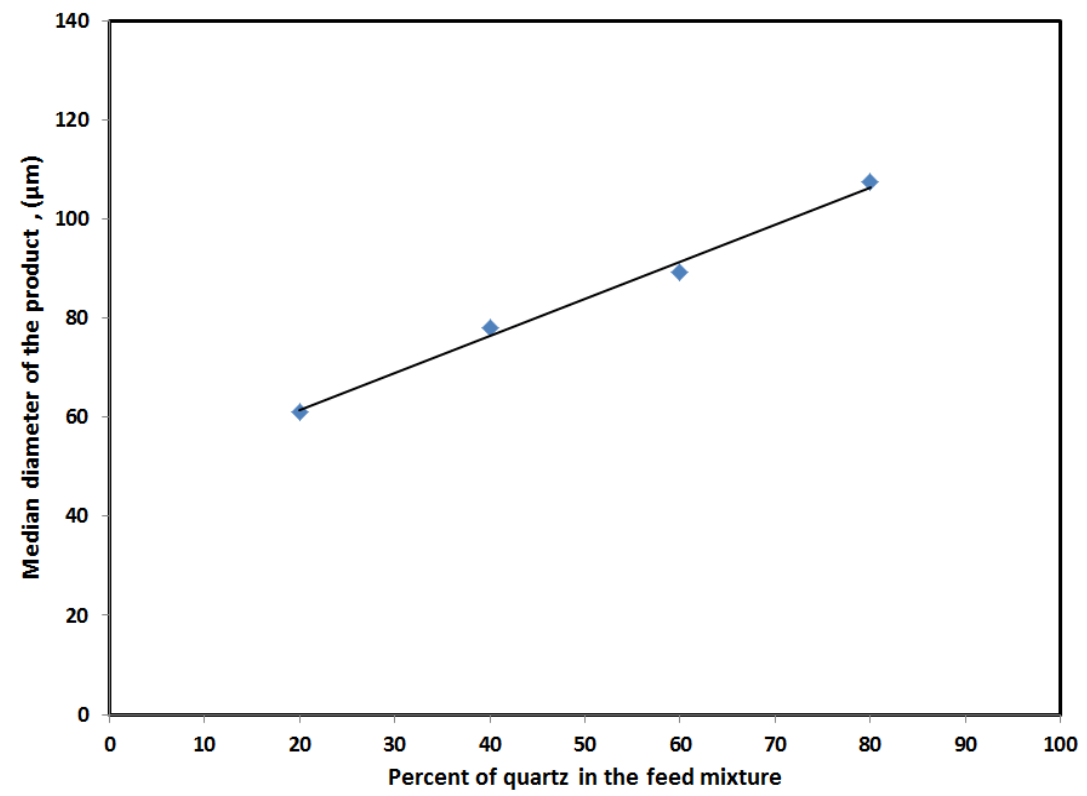

Fig. (3) Effect of the percentage of quartz in the median diameter of the product. 


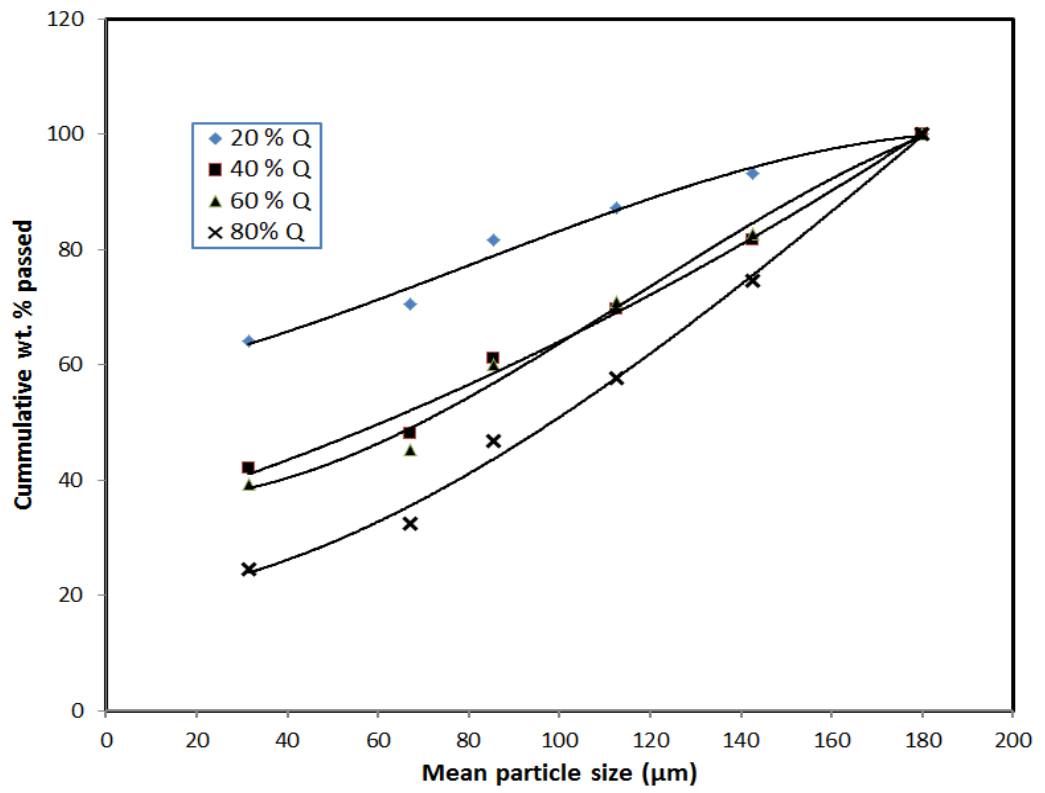

Fig. (4) Particle size distributing of the ground mixture undersize $(-200 \mu \mathrm{m})$ at the steady state conditions. 


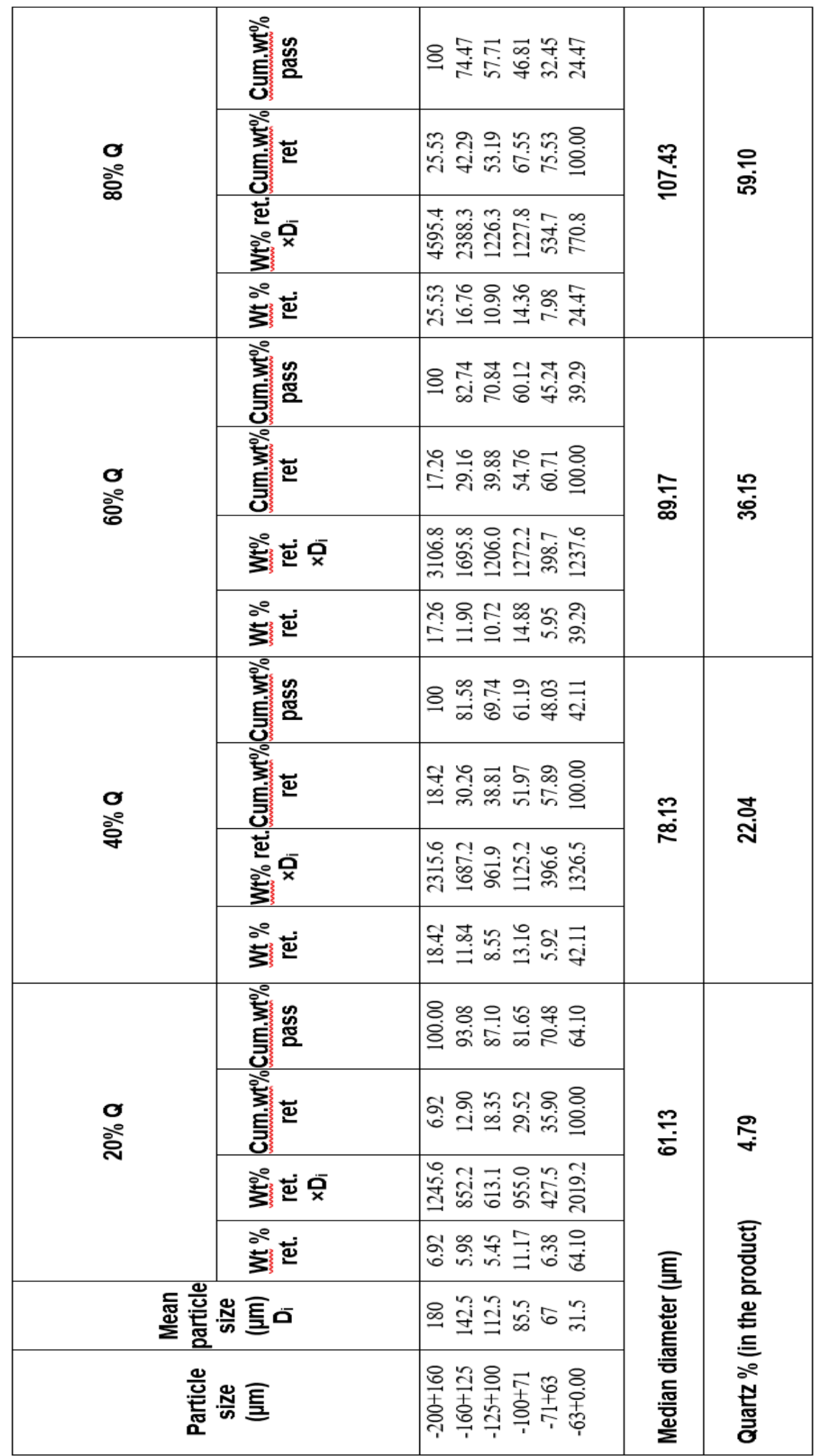




\section{Conclusions}

From this study it can be concluded that:

- Attaining the steady state in a fixed time locked-cycle is faster with low circulating load and final product for soft material (limestone) if compared with those for hard material (quartz) when they ground separately.

- For the admixture, increasing the percentage of the hard component in the feed increases its appearance gradually in the product. This increase is accompanied with decrease in the fineness of product and increase in the time arrival of the steady state.

\section{Acknowledgment}

The experimental work of this study was performed in mineral processing laboratories, in Mining and Metallurgical Engineering Department, Faculty of Engineering, Assiut University. Assistance of the staff members and technicians of this field are gratefully acknowledged.

\section{References}

[1] Remes, A., Aaltonen, J., and Koivo, H., "Grinding circuit modelling and simulation of particle size control”, Int.J. of miner. Process., Vol.96 (2010), pp.70-78.

[2] Rodriguez, B.A., Menendez-Aguado, J.M., Coello Velazquez, A., and Dzioba, B.R., "Transient state analysis by simulation in a closed grinding circuitTechnical note", Minerals Engineering, Vol.24 (2011), pp.473-475.

[3] Khumalo, N., Glasser, D., Hildebrandt, D., and Hausberger, B., "Improving comminution efficiency using classification: An attainable region approach", Powder Techn., Vol.187 (2008), pp.252-259.

[4] Brown, R.L., Chem, M.I., "Calculation of closed-circuit grinding", British Chemical Engineering, August / September, (1959), pp.463-466.

[5] Stewart, P.S.P., and Restarick, C.J., "Dynamic flow characteristics of a small spiral classifier”, Trans.of IMM. Sec. C., Vol.76, (1967), pp.C225-C230.

[6] Kapur, P.C., and Rahman, M., "Simulation of fixed time locked-cycle grinding tests", Trans. Of IMM, Sec.C., Vol.80, (1971), pp. C74-C78.

[7] Karra, v.k., "Calculating the circulating load in crushing circuits", Eng. And Mining Journal, Feb. (1979), pp.66-68.

[8] Cemil Acar and Hosten Certin, "Grinding Kinetics of steady state feeds in locked-cycle dry ball milling", Powder Techn., Vol. 240, (2013), pp. 274-281.

[9] Shengo, L.M., Gydardzhiev, S., and Kalenga, N.M., "Malachite and heterogenite behavior during the locked-cycle recycling of process water in 
flotation of copper-cobalt oxide ores". Int.J. of Miner. Process., Vol.157, (2016), pp. 152-162.

[10] Hartlieb, p., Toifl, M., Kuchar, F., Meisels, R., and Antretter, T., "Thermophysical properties of selected hard rocks and their relation to microwaveassisted comminution", Minerals Engineering, Vol.91 (2016), pp.34-41.

[11] Altun, A., Benzer, H., Dundar, H., and Aydogan, N.A., "Comparison of open and closed circuit HPGR application on dry grinding circuit performance", Mineral Engineering, Vol.24 (2011), pp.267-275.

[12] Fuerstenau, D.W., and Venkataraman, K.S., "The comminution of multi component feeds under batch and Locked-cycle conditions: Kinetics, simulation and energy distribution", Int.J. of Miner. Process., Vol.22 (1988), pp.105-118.

[13] Kapur.P.C., Verma, R., Velamakanni, B.V., and Fuerstenau, D.W., "Simulation of locked-cycle grinding of multi component feeds and its implications for stability and control of industrial comminution circuits", Powder Techn, Vol.69, (1992), pp.77-84.

[14] Kapur.P.C., and Fuerstenau, D.W., "Simulation of locked-cycle grinding tests using multi component feeds", Powder Techn., Vol.58 (1989), pp.39-48.

[15] Powell, M.S., and Morrison, R.D., "The future of commnution modelling", Int.J. Min. Process, Vol. 84 (2007), pp. 228-239.

[16] Jankovic, A., and Valery, W., "Closed circuit ball mill -revisited", Minerals Engineering, Vol.43-44 (2013), pp. 148-453.

[17] Olivera, A., and Tawares, L.M., "Modelling and simulation of continuous open circuit dry grinding in a pilot-scale ball mill using Austin and Nomura's models", Powder Techn., Vol.340 (2018), pp.77-87.

[18] Weining, X., yaqun, H., Zhenzhou, G., Fengnian, S., yong, y., Hong, L., Shuai, W., and ki, L, "An analysis of the energy split for grinding coal / calcite mixture", Minerals Engineering, Vol.93 (2016), pp. 1-9.

[19] Dundar, H., and Benzer, H., "Investigation multicomponent breakage in cement grinding", Minerals Engineering, Vol.77 (2015), pp.131-136.

[20] Genc, O., "Optimization an industrial scale open circuit three-compartment cement grinding ball mill with the aid of simulation", Int.J. of Miner. Process., Vol.154 (2016), pp.1-9. 
"دراسة سلوك طحن خليط ذو مكونين باستخدام اختبارات دائرة الطحن المغلقة ذات القترات الزمنية الثابتة"

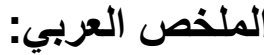

الخامات عامة غير متجانسة في خو اصها الطبيعية، ويؤدى اختلاف هذه الخو اص إلى ، اختلاف سلوك طحنها، لذا بتطلب الأمر دراسة سلوك مكونات هذه الصخور وكيفية تصرفها مع بعضها أثناء الطحن ليس فقط من أجل عملها أثناء الطحن ولكن يفيد ذلك أيضا في الوصول إلى القيم المتلى التي تستخدم في عمليات النمذجة الرياضية. توضح اختبار ات الدائرة المغلقة للمخاليط أن هنالك وقت طويل تحتاجه للوصول إلى حالة الاتزان التي أثناؤه تختلف هذه المكونات بمرور زمن الطحن. لذا فالهدف الرئيسي من إجراء هذا البحث هو دراسة سلوك خليط من الكوارتز و الحجر الجيري عند نسب خلط مختلفة من بداية التشغيل حتى الوصول إلى حالة الاتزان باستخدام اختبار ات الطدن في الدائرة المغلقة ذات الفتر ات الزمنية الثابتة. وقد أوضحت الدر اسة أن زمن الوصول إلى حالة الاتزان يكون أسرع و الحمل الدوار يكون أقل ودرجة نعومة المنتج تكون أكبر بالنسبة للخام الأقل صلابة (الحجر الجيري)

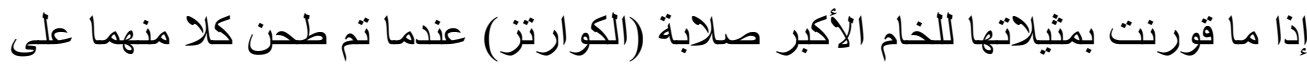
حده. و عند در استهما كخليط بنسب خلط مختلفة تظهر نسبة المكون الأصلب تدريجيا بزيادة نسبته في خام التغذية مع قلة درجة نعومة المنتج النهائي وزيادة زمن الوصول

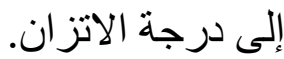

